\title{
The Impact of The Covid-19 Pandemic on Poverty Gap in Indonesia
}

\author{
Ernawati $^{1 *}$, Tajuddin ${ }^{2}$ \\ ${ }^{1,2}$ Department of Economics and Development Studies, Faculty of Economics and Business, Halu Oleo University, Indonesia \\ *Corresponding author. Email: ernawaty@uho.ac.id
}

\begin{abstract}
The COVID-19 pandemic has driven the incidence of poverty. However, how the pandemic affects the poverty gap is less studied. This study analyzes the poverty gap in urban and rural of Indonesia during the pandemic. The research uses secondary data published by Statistics Indonesia for 2019 and 2020, wherein the analysis units are all the provinces in Indonesia. The gap poverty index measures the poverty gap. The impact of the pandemic was estimated by testing the difference in the gap poverty before the pandemic (2019 period) compared to the gap poverty during the COVID-19 pandemic (2020 period), specifically in the first and second semester. Paired and independent sample t-tests were used for data analysis. The results show different poverty gaps in urban and rural areas of Indonesia before and during the pandemic. The pandemic triggers an increase in the poverty gap in urban areas driven by economic contraction, especially the service sector. Although the population of poor people in Indonesia's urban areas has increased higher than in rural areas during the pandemic, the poverty gap in rural areas is higher than in urban areas. Therefore, social safety net programs also need to consider the rural besides in urban areas.
\end{abstract}

Keywords: gap, poverty, urban, rural

\section{INTRODUCTION}

The COVID-19 pandemic created uncertainties regarding economic and social policies [1]. The pandemic drove nearly 150 million people to extreme poverty which was much deeper than the financial crisis in 2008-2009 [2]. Compared to September 2019, the poverty gap in Indonesia has increased by .97 percent or about 2.76 million in September 2020 [3]. Figure 1 shows that the urban poverty rate in September 2020 was at 7.88 percent, while at 13.20 percent in rural areas. The impact of the pandemic was higher in urban areas than in rural Indonesia, as indicated by an increase in the urban poor population during the pandemic by 1.32 percent, while in rural areas, it was .6 percent. The increase in the lower poverty rate in rural areas is since rural communities have a livelihood in the agricultural sector. During the peak of the pandemic, the agricultural sector did not experience contraction, instead of showing an economic expansion of 2.15 percent in September 2020 [4].

The poverty gap in Indonesia also increased due to the pandemic, from 1.50 percent in September 2019 to 1.75 percent in September 2020. Regionally, the poverty gap in rural areas was higher than in urban areas, even though rural areas were dominated by the agricultural sector, which did not generally experience contraction during the COVID-19 pandemic. The rural poverty gap in September 2019 was at 2.11 and increased to 2.39 in September 2020, while the urban poverty gap in September 2019 was at 1.02 and increased to 1.13 in September 2020 [5]. Therefore, the study of poverty needs to focus on the size of the poverty gap. The incidence of poverty is the most popular measure in analyzing the problem of poverty. This index measures the number of people who have consumption levels below the poverty line, however, this measure does not consider whether a poor person becomes poorer or becomes more prosperous. The Poverty Gap Index, measures the average decline in aggregate consumption against the poverty line for the entire population. This measure helps provide information on how many resources are needed to reduce poverty, such as cash transfers targeted appropriately to the poor, especially in the national economic recovery program due to the economic slowdown in the pandemic.

Estimating the poverty in the pandemic period in Indonesia has been studied [6], but this array of knowledge uses poverty incidence measurements. However, the study as to the effect of the pandemic using indicators of the poverty gap is less studied. Other studies [7] only examined the poverty gap between women and men due to the pandemic. This study focuses on indicators of the poverty gap by distinguishing between urban and rural. The poverty gap in urban and rural is expected to provide information in determining resources for regional-based poverty management. The poverty study during the COVID-19 pandemic is likely to be relevant to the need to measure fiscal stimulus for poor communities affected by the pandemic. 


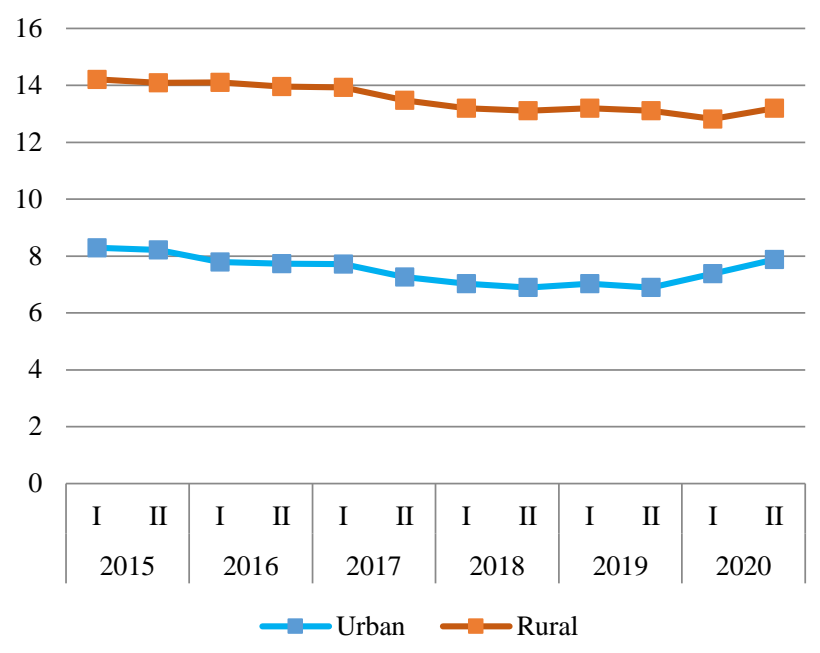

Source: BPS (2021a) processed

Figure 1 Poverty Rate in Indonesia's Urban and Rural Areas in 2015-2020

\section{METHOD}

This study uses secondary data published by Statistics Indonesia for 2019 and 2020. The unit of research analysis is all provinces in Indonesia. The poverty gap is measured by the poverty gap index. The impact of the pandemic is measured by testing the difference between the poverty gap before and during the pandemic. The period before the pandemic is 2019, and the pandemic period is 2020 for semester 1 (March) and semester 2 (September). The March 2020 period introduced the initial COVID-19 infection case in Indonesia. Paired sample t-test (equation 1) was conducted to assess the impact of the pandemic. To find out the difference in the effects of COVID-19 in urban and rural areas, an independent sample t-test (equation 2) was carried out. The data is processed using SPSS. Before estimating the difference test, the data normality test and the variance similarity test (homogeneity) were carried out with the F test (Levene's Test). If the significance of Levene's Test is > .05, it means that the variance of the two groups is the same, then the t-test uses equal variance assumed, and vice versa if Levene's Test is $<.05$, this shows that the variance of the two groups is different, then the t-test uses equal variance not assumed. The equal variance assumed formula is presented as equation (2).

$$
\begin{aligned}
& \mathrm{t} 1=\frac{\bar{d}}{(S d / \sqrt{n})} \\
& \mathrm{t} 2=\frac{\bar{X}_{1}-\bar{X}_{2}}{\sqrt{\frac{\left(n_{1}-1\right) S_{1}^{2}+\left(n_{2}-1\right) S_{2}^{2}}{n_{1}+n_{2}-2}\left(\frac{1}{n_{1}}+\frac{1}{n_{2}}\right)}}
\end{aligned}
$$

where:

$\bar{d}=$ mean the difference between paired observations

$\mathrm{t}=$ distribution value $\mathrm{t}$

$\bar{X}=$ mean of sample

$S_{d}=$ standard deviation

$S_{i}^{2}=$ variance of sample

$\mathrm{n}=$ number of samples

The hypotheses proposed in this study are:

1. The COVID-19 pandemic has affected the poverty gap in urban areas.

H1.1 There is a difference in the poverty gap in the March period, before and during the pandemic in urban areas.

H1.2 There are differences in the poverty gap in September, before, and during the pandemic in urban areas.

H1.3 There is a difference in the poverty gap in urban areas between March and September during the pandemic.

2. The COVID-19 pandemic has affected the poverty gap in rural areas.

H1.4 There is no difference in the poverty gap in the March period, before and during the pandemic in rural areas.

H1.5 There is a difference in the poverty gap in September, before and during the pandemic in rural areas.

H1.6 There is a difference in the poverty gap between March and September during the pandemic in rural areas.

3. The poverty gaps in urban and rural areas before and during the COVID-19 pandemic are different.

H1.7 The poverty gap in the March period before the pandemic in urban and rural areas is different.

H1.8 The poverty gap in March period during the pandemic in urban and rural areas is different.

H1.9 There are differences in poverty gaps for the September period, before the pandemic in urban and rural.

H1.10 There are differences in the poverty gap in the September during the pandemic in urban and rural.

\section{RESULTS AND DISCUSSION}

\subsection{Results}

The Normality test show that all estimated variables are not normally distributed with a substantial positive skewness curve slope. The data is transformed to Log 10 . The results of the test of the data transformation are presented in Table 1. The research data were normally distributed, indicated by the significance value of both Shapiro-Wilk and Kolmogorov-Smirnov > 0.05 . 
Table 1. Normality Test

\begin{tabular}{|c|c|c|c|c|c|}
\hline \multirow[t]{2}{*}{ Region } & \multirow[t]{2}{*}{ Period } & \multicolumn{2}{|c|}{$\begin{array}{l}\text { Kolmogorov- } \\
\text { Smirnov }\end{array}$} & \multicolumn{2}{|c|}{ Shapiro-Wilk } \\
\hline & & Statistic & Sig. & Statistic & Sig. \\
\hline \multirow[t]{4}{*}{ Urban } & 2019 March & .118 & .200 & .979 & .730 \\
\hline & 2019 Sept & .115 & .200 & .970 & .460 \\
\hline & 2020 March & .089 & .200 & .975 & .599 \\
\hline & 2020 Sept & .091 & .200 & .980 & .763 \\
\hline \multirow[t]{4}{*}{ Rural } & 2019 March & .115 & .200 & .994 & .176 \\
\hline & 2019 Sept & .132 & .153 & .966 & .379 \\
\hline & 2020 March & .109 & .200 & .960 & .261 \\
\hline & 2020 Sept & .132 & .153 & .953 & .160 \\
\hline
\end{tabular}

Source: Secondary data, processed

Estimation results of the poverty gap difference, before and during the pandemic are presented as Table 2, with the following results:

a. The difference in the poverty gap in the March period, before and during the pandemic of urban areas, is not significant. Therefore, hypothesis H1.1 is rejected.

b. The difference in the poverty gap in September before and during the pandemic of urban areas is significant. The average value of the poverty gap for the September 2020 period is higher than the September 2019 period. Therefore, hypothesis H1.2 is accepted.

c. There is a difference in the poverty gap in the March and September periods during the pandemic in urban areas as indicated by a significant value of $.000<.05$, with the average poverty gap for the March 2020 period lower than the September 2020 period. Therefore, the hypothesis H1.3 is accepted.

d. The difference in the poverty gap in the March period, before and during the pandemic of rural areas, is not significant. Therefore, the H1.4 hypothesis is rejected.

e. The difference in the poverty gap in September before and during the pandemic of rural areas is significant. The average value of the poverty gap for the September
2020 period is higher than the September 2019 period. Therefore, hypothesis H1.5 is accepted.

f. There is a difference in the poverty gap in the March and September periods during the pandemic in rural areas as indicated by a significance value of $.000<.05$ with the average poverty gap in the March 2020 period lower than the September 2020 period. Therefore, the hypothesis H1.6 is accepted.

After testing the similarity of variance (homogeneity) indicated by the significance of the F test (Levene's Test), Table 3 shows that there is a similarity of variance between the urban and rural poverty gaps for the entire period, which is estimated with a significance value $>.05$. Furthermore, hypothesis testing showed a difference in the poverty gap between urban and rural areas in the entire estimated period (Table 4), with a significance value of $.000<.05$. Therefore, the research hypotheses H1.7, H1.8, H1.9, and H1.10 are accepted.

The negative mean difference value (where group $1=$ urban; and group 2 = rural) indicates that the average poverty gap in urban areas in Indonesia is lower than in rural areas. On the other hand, the poverty gap between rural and urban is narrowing as indicated by the mean difference value, declining from .298 in March 2019 to .296 in September 2019. During the COVID-19 pandemic in March, the mean difference between the two groups decreased to 0.284 , and in the September 2020 period, it became 0.265.

\subsection{Discussion}

The poverty gap in September, before and during the pandemic, in urban and rural is different. In September 2020, Indonesia had several COVID-19 cases that had exceeded the psychological number of 100,000 infection cases. From April to September 2020, 34 regencies and cities implemented large-scale social restrictions. Even distance restrictions are consistently enforced, as well as work and school from home. As a result, the economy experienced a contraction that prompted layoffs in various sectors.

Table 2 Estimation Results of the Difference in the Poverty Gap Before and During the Covid-19 Pandemic

\begin{tabular}{|c|c|c|c|c|c|c|}
\hline Region & Period & Mean & $\begin{array}{l}\text { Std. } \\
\text { Deviation }\end{array}$ & $\mid \begin{array}{ll}\text { Std. } & \text { Error } \\
\text { Mean } & \end{array}$ & & $\begin{array}{l}\text { Sig. } \\
\text { (2-tailed) }\end{array}$ \\
\hline \multirow[t]{3}{*}{ Urban } & 2020 (March) to 2019 (March) & .022 & .076 & .013 & 1.670 & .104 \\
\hline & 2020 (Sept) to 2019 (Sept) & .086 & .107 & .018 & 4.712 & .000 \\
\hline & 2020 (Sept) to 2020 (March) & .053 & .046 & .008 & 6.811 & .000 \\
\hline \multirow[t]{3}{*}{ Rural } & 2020 (March) to 2019 (March) & .007 & .050 & .009 & .762 & .452 \\
\hline & 2020 (Sept) to 2019 (Sept) & .051 & .066 & .011 & 4.455 & .000 \\
\hline & 2020 (Sept to 2020 (March) & .034 & .019 & .003 & 10.254 & .000 \\
\hline
\end{tabular}

Source: Secondary data, processed 
Table 3 Test for Equality of Poverty Gap Variances Between Urban and Rural Areas

\begin{tabular}{|l|l|r|r|}
\hline \multicolumn{2}{|l|}{ Period } & \multicolumn{2}{l|}{ Levene's Test } \\
\cline { 3 - 4 } \multicolumn{2}{l|}{} & \multicolumn{1}{l|}{ F } & Sig. \\
\hline 2019 & March & .991 & .323 \\
\cline { 2 - 4 } & Sept & .638 & .427 \\
\hline 2020 & March & .744 & .392 \\
\cline { 2 - 4 } & Sept & 1.361 & .248 \\
\hline
\end{tabular}

Source: Secondary data, processed

Table 4 T-test for Equality of Poverty Gap Means Between Urban and Rural Areas

\begin{tabular}{|c|c|c|c|c|c|}
\hline \multicolumn{2}{|c|}{ Period } & t & $\begin{array}{l}\text { Sig. } \\
\text { (2-tailed) }\end{array}$ & $\begin{array}{l}\text { Mean } \\
\text { Difference }\end{array}$ & $\begin{array}{c}\text { S. E. } \\
\text { Difference }\end{array}$ \\
\hline \multirow[t]{2}{*}{2019} & March & 4.689 & .000 & .298 & .064 \\
\hline & Sept & 4.448 & .000 & .296 & .067 \\
\hline \multirow[t]{2}{*}{2020} & March & 4.454 & .000 & .284 & .064 \\
\hline & Sept & 4.351 & .000 & .265. & .061 \\
\hline
\end{tabular}

Source: Secondary data, processed

The pandemic has affected 2.56 million unemployed people [4]. As a result, household incomes declined and encouraged an increase in poverty. The decline in income of the poor increasingly pushes them away from the needs of a decent life. The poor suffered the worst impact of COVID19 which is decreased food consumption [8],[9]. The decline in consumption expenditure, especially food for the poor, is much higher than for middle- and high-income people [10]. The negative economic impact of the pandemic is concentrated on low incomes before the pandemic [11]. The COVID-19 pandemic has pushed the poor away from the poverty line, therefore increasing the poverty gap. This phenomenon appears not only in urban areas but also in rural areas. Previous studies in China show that 23 percent of rural household respondents in China think they will fall into poverty again because of the pandemic [12].

The results also show differences in the poverty gap between March and September during the pandemic in the urban and rural. March was the initial period of COVID-19 infection cases in Indonesia, and it has not significantly impacted where people continue to carry out their activities as usual, except for some sectors that enforced work from home. Although the poverty gap increased in the March period, the increase was still lower than in the September 2020 period. The results showed no difference in the poverty gap between March 2020 and March 2019 in urban and rural areas. In the March 2020 period, panic has not occurred, and the economy, in general, is still regular. Therefore, despite the economic slowdown, it has not significantly impacted the poverty gap between March 2020 and March 2019.

Economic contraction generally occurs in the nonagricultural sector, especially the service sector operating in urban areas. The service sector was the hardest hit during the pandemic because this sector can be delayed in consumption, such as transportation, restaurants, and hotels. Transportation and warehousing suffer the most contraction, and provision of accommodation and food and drink [4]. The economic contraction in these sectors ultimately has an impact on higher urban poverty. Global research shows an increasing trend in poverty with a more severe impact in urban than in rural areas of South Asia and sub-Saharan Africa [2]. However, this study results show differences in the poverty gap for all the estimated periods where the poverty gap is higher in rural, and this pattern has not shifted from the pre-and during-pandemic periods. Although the population of poor people in Indonesia's urban areas has increased higher than that of rural areas, namely 1.32 percent for the September 2020 period in urban areas and 0.6 percent in rural areas, the pandemic has resulted in a higher poverty gap in rural areas. Therefore, social safety nets are also needed in rural areas. Social safety nets can reduce the risk of people into poverty [13],[14].

COVID-19 has also had an enormous impact on informal sector workers [15]. Informal sector workers are economically marginalized and have little social protection [16]. Most informal sector workers in Indonesia who lost jobs worked in non-agricultural areas [17]. Informal workers do not have an employment contract, have no proper security, have low wages, and operate without a business license. The impact of a pandemic on informal sector workers is further exacerbated by discrimination. In cities worldwide, informal workers face increased police violence, dislocation from employment sources through increased discrimination, and stigmatization as virus vectors [18].

\section{CONCLUSION}

The COVID-19 pandemic significantly drove the poverty gap. The average poverty gap for the September 2020 period was higher than the March 2020 and September 2019 periods. The increase in the poverty gap in urban areas is caused by the most profound economic contraction in the service sector, especially transportation and warehousing and accommodation, and food and drink based in urban areas. The contraction is derived from weak demand because the nature of their services is that they can be postponed. Contrast this with rural output, which is generally based on agriculture, especially food crops. Demand is still increasing, encouraging this sector to continue to grow despite experiencing a slowdown. Although the agricultural sector continues to grow and the service sector contracts, the poverty gap in rural areas is higher than in urban. The poverty gap between urban and rural is different throughout the estimated period, where it is higher in rural areas, and this pattern has not shifted from before and after the pandemic. Therefore, rural communities must be included in the social safety nets program. Social safety nets programs in urban areas are directed at the poor, the most impacted sectors, and the informal sector workers. 


\section{REFERENCES}

[1] P.A. Vitenu-Sackey, R. Barfi, "The Impact of Covid-19 Pandemic on the Global Economy: Emphasis on Poverty Alleviation and Economic Growth" The Economics and Finance Letters 8(1) (2021) 32-43. DOI: 10.18488/journal.29.2021.81.32.43

[2] D. Laborde, W. Martin, R. Vos, "Impacts of COVID-19 on global poverty, food security, and diets: Insights from global model scenario analysis", Agricultural Economics (United Kingdom) 52(3) (2021) 375-390. DOI: https://doi.org/10.1111/agec.12624

[3] Statistics Indonesia. (2021a). Persentase Penduduk Miskin September 2020 naik menjadi 10,19 persen. Available online: https://www.bps.go.id/pressrelease/ 2021/02/15/1851/persentase-penduduk-miskin-septem ber2020-naik-menjadi-10-19-persen.html (accessed on 3 July 2021)

[4] Statistics Indonesia. (2020). Berita Resmi Statistik Pertumbuhan Ekonomi Indonesia Triwulan III. Available online: https://www.bps.go.id/website materi_ind/materiBrsInd-20201105120056.pdf (accessed on 9 July 2021)

[5] Statistics Indonesia. (2021b). Indeks Kedalaman Kemiskinan (P1) Menurut Provinsi (Persen), 2020-2021. Available online: https://www.bps.go.id/indica tor/23/503/1/indekskedalaman-kemiskinan-p1-menur ut-provinsi.html (9 July 2021)

[6] A. Suryahadi, R. Al Izzati, D. Suryadarma, "Estimating the Impact of Covid-19 on Poverty in Indonesia", Bulletin of Indonesian Economic Studies 56(2) (2020) 175-192. DOI: http://dx.doi.org/10.1080/00074918.2020.1779390

[7] J. Cuesta, J. Pico, "The Gendered Poverty Effects of the COVID-19 Pandemic in Colombia" European Journal of Development Research 32(5) (2020) 1558-1591. DOI: https://doi.org/10.1057/s41287-020-00328-2

[8] O. Coibion, Y. Gorodnichenko, M. Weber, "The Cost of the COVID-19 Crisis: Lockdowns, Macroeconomic Expectations, and Consumer Spending", SSRN Electronic Journal. 2020. DOI: https://doi.org/10.2139/ssrn.3593469

[9] M. Chen, "COVID-19, Cities and Urban Informal Workers: India in Comparative Perspective", Indian Journal of Labour $\begin{array}{lllll}\text { Economics } & 63 & \text { (2020) S41-S46. DOI: }\end{array}$ https://doi.org/10.1007/s41027-020-00254-1

[10] E. Ernawati, W. Maguni, Dampak Pandemi Covid-19 Terhadap Pengeluaran Konsumsi dan Perilaku Berbelanja Masyarakat di Indonesia, in: Proceeding Seminar \& Call For Papers Building Sustainability through Adaptation in the Global and Intense Dynamic Environment, Fakultas Ekonomika dan Bisnis UKSW, Salatiga, Indonesia, 2021, pp. 939-956.

[11] N. Bottan, B. Hoffmann, D. Vera-Cossio. "The unequal impact of the coronavirus pandemic: Evidence from seventeen developing countries", PLoS ONE 15(10) (2020). DOI: https://doi.org/10.1371/journal.pone.0239797

[12] R. Luo, C. Liu, J. Gao, T. Wang, H. Zhi, P. Shi, J. Huang, "Impacts of the COVID-19 pandemic on rural poverty and policy responses in China", Journal of Integrative Agriculture 19(12) (2020) 2946-2964. DOI: https://doi.org/10.1016/S2095-3119(20)63426-8

[13] K. Caminada, K. Goudswaard, F. Koster, "Social income transfers and poverty: A cross-country analysis for OECD countries" International Journal of Social Welfare 21(2) (2012). DOI: $\quad$ https://doi.org/10.1111/j.14682397.2011.00815.x

[14] R. Miežiene, S. Krutuliene, "The Impact of Social Transfers on Poverty Reduction in EU Countries", Baltic Journal of
European Studies 9(1) (2019) 157-175. DOI: https://doi.org/10.1515/bjes-2019-0009

[15] M.I. Hossain, "COVID-19 Impacts on Employment and Livelihood of Marginal People in Bangladesh: Lessons Learned and Way Forward", South Asian Survey 28(1) (2021) 57-71. DOI: https://doi.org/10.1177/0971523121995072

[16] W. Komin, R. Thepparp, B. Subsing, D. Engstrom, "COVID-19 and its impact on informal sector workers: a case study of Thailand", Asia Pacific Journal of Social Work and Development 31(1-2) (2021) 80-88. DOI: https://doi.org/10.1080/02185385.2020.1832564

[17] A.J. Pitoyo, B. Aditya, I. Amri, The impacts of COVID-19 pandemic to informal economic sector in Indonesia: Theoretical and empirical comparison, in Proceeding The $1^{\text {st }}$ Geosciences and Environmental Sciences Symposium, E3S Web Conf. (200), 2020. DOI: https://doi.org/10.1051/e3sconf/202020003014

[18] H. Chen, W. Qian, Q. Wen, "The Impact of the COVID-19 Pandemic on Consumption: Learning from High Frequency Transaction Data", SSRN Electronic Journal. (2020). DOI: https://doi.org/10.2139/ssrn.3568574 